\title{
Affect and trust as predictors of public support for armed police: Evidence from London
}

\author{
Julia A. Yesberg* and Ben Bradford
}

Jill Dando Institute of Security and Crime Science, University College London, London, United Kingdom

* Julia Yesberg, Jill Dando Institute of Security and Crime Science, 35 Tavistock

Square, London WC1H 9EZ, United Kingdom, +44 (0)20 3108 3206,

J.Yesberg@ucl.ac.uk

Ben Bradford, Jill Dando Institute of Security and Crime Science, 35 Tavistock Square, London WC1H 9EZ, United Kingdom, +44 (0)20 3108 3206, B.Bradford@ucl.ac.uk

Julia A. Yesberg completed her PhD in the School of Psychology at Victoria University of Wellington, New Zealand, and is currently a Research Associate in the UCL Jill Dando Institute of Security and Crime Science in London. Her research interests include the rehabilitation and reintegration of high-risk offenders, risk assessment, disproportionately and vulnerability, and public perceptions of the police and criminal justice system.

Ben Bradford is Director of the Institute for Global City Policing at the UCL Jill Dando Institute of Security and Crime Science. His research interests include procedural justice theory, public trust, and police legitimacy. His book, Stop and Search and Police Legitimacy, was published in 2017; he is also editor, along with Beatrice Jauregui, Ian Loader and Jonny Steinberg, of the SAGE Handbook of Global Policing (2016).

\section{Acknowledgements}

The authors would like to thank the Mayor's Office for Policing And Crime - in particular Dr Paul Dawson - for access to the data used in this study.

Word count: 10,181 words 


\title{
Affect and trust as predictors of public support for armed police: Evidence from London
}

\begin{abstract}
Police in England, Scotland and Wales operate largely unarmed, and have done since the formation of the London Metropolitan Police in 1829. However, recent terror attacks and concern over serious violent crime have prompted increased funding for armed officers and even calls for routine arming of police. In this paper we present results from the first in-depth study of public attitudes toward the arming of more police. Starting from the assumption that most people have little concrete knowledge of the potential benefits and risks of doing so, we show that trust, and particularly affective responses to the idea of armed police, are central in shaping support for the routine arming of more officers. A range of other sociological and psychological variables are also important, but only in as much as they are correlated with trust and, again, particularly affect. Our findings have implications not only for this specific policy development, but also wider consideration of lay reactions to changes in police policy and technology.
\end{abstract}

Keywords: armed police; affect; public trust; attitudes

\section{Introduction}

The idea of British policing has, for almost 200 years, rested on the twin pillars of 'policing by consent' and the notion that the police force's primary duty is to the public, rather than the state. The image of the 'British bobby' - an unarmed neighbourhood constable with powers not so different from the public at large - symbolizes a style of policing that, culturally and ideologically, sets Britain apart from much of the rest of Europe. However, recent terrorist events in the UK and Europe have fuelled debate over whether police officers in England, Wales and Scotland should be routinely armed. ${ }^{1}$ In a

\footnotetext{
${ }^{1}$ The situation in Northern Ireland is of course quite different, and police there have been routinely armed for many years. In this article we concentrate on England and Wales and, in particular, London.
} 
context where very few citizens have access to guns, and where the police have never before been routinely armed, this would represent a significant break with the past.

The UK's counter-terrorism strategy CONTEST aims 'to reduce the risk to the UK and our interests overseas from terrorism so that people can go about their lives freely and with confidence' (Home Office 2011, p. 18). One aspect of the strategy is to protect the public against a terror attack by: strengthening UK border security measures, reducing the vulnerability of the transport network, increasing resilience of the UK's infrastructure, and increasing resilience against terrorism in 'crowded places' (e.g. by increasing the presence of police officers, including those carrying firearms; Home Office 2011). Alongside this strategy, and in direct response to the terrorist attacks in Paris in November 2015, the Metropolitan Police Service (MPS) announced the Home Office had pledged an extra $£ 34$ million to increase police firearms capacity and that the MPS would train an extra 600 armed police officers in London (BBC 2016).

As of 31 March, 2017, there were 6,278 armed police in England and Wales (5\% of the entire service), of which 2,394 were within the MPS (accounting for $8 \%$ of all MPS officers). This compares with 5,647 armed police in England and Wales (4\% of all officers), of which 2,122 were in the MPS (7\% of all officers), two years earlier (on 31 March 2015). Although these numbers are small compared to other police organisations in Europe and most of the rest of the world, the increase in police firearms capacity in the UK raises questions about how an armed police presence aligns with the British model of policing and the notion that police officers are 'civilians in uniform'. Very little research has measured public perceptions of armed police in the UK; however, findings from online polls show opinion is mixed. In one sample, $58 \%$ of people believed police officers should be routinely armed, whereas $42 \%$ were opposed (BMG Research 2015). Opinion is also mixed among police officers, although a majority 
appear to be against routine arming. A recent survey by the Police Federation showed $34 \%$ of officers believed the police should be routinely armed, up from $23 \%$ when the survey was last conducted in 2006 (Police Federation 2017). However, 55\% of officers said they would be prepared to carry a firearm if instructed to do so (an increase from $45 \%$ in the 2006 survey).

There are two interlinked sets of questions here. First, what shapes public attitudes toward armed police in a context where people are not used to this form of policing? Does the presence of a firearm change the way they interact with and perceive the police? Second, what informs public acceptance of - or opposition to - policies that increase the number and visibility of armed police? And how do attitudes flow into policy preference? In this paper we concentrate on people's emotional response to armed police (i.e. their 'affect', how they say armed police makes them feel), and how people think about policy changes that would increase the number of armed police 'on the streets'. To our knowledge this is the first attempt to explore in any depth public perceptions of armed police in London, and indeed Great Britain as a whole. We aim to chart variation in opinion across different groups, and develop understanding of the factors that influence attitudes toward armed police: asking, who supports the arming of police officers, who does not, and why?

The paper proceeds in five main parts. After briefly outlining the history of armed police in England, Wales and Scotland, and the arguments for increasing the presence of armed police in the wake of recent terrorist attacks, we turn to a discussion of how the interlinked concepts of trust and affect, and, through them, a wide range of social and psychological variables, may shape people's views of armed police. Having outlined a range of potential predictors, subsequent sections cover data and methods, 
results and discussion. We conclude by outlining some of the wider implications of our findings.

\section{Armed police in England, Wales and Scotland}

When the Metropolitan Police was first created in London in 1829, a decision was made that police officers would go about their work unarmed. An unarmed service has continued to be the hallmark of policing in the UK, with the only routinely armed forces being the Police Service of Northern Ireland, the Ministry of Defence Police and the Civil Nuclear Constabulary. Yet debate about this issue is far from a recent phenomenon and police policy around arming officers has experienced a number of significant shifts and about-turns. Historically, calls for the police to be routinely armed have been made following incidents in which police officers or civilians have been killed or injured by an armed assailant. On 22 September 1881, after an unarmed police officer was shot and killed on night duty patrol in South London, it was decided that officers who wished to carry a firearm on night duty could do so (Waldren 2007). Although this policy was eventually discarded in 1936, following the murder of a Constable in 1952, and three police officers in 1966, police leaders again decided to significantly increase the number of officers authorised to carry firearms. Control was once again tightened in the 1980 s following a number of incidents in which police fatally shot civilians; however, since this time, there has been a gradual increase in the number of police officers carrying firearms due to the rising threat of serious violence and terrorism. Additionally, since the mid-1990s Home Office forces have had armed response vehicles (ARVs) patrolling the streets to provide an immediate firearms response.

The debate to arm more (or all) police is often framed not only in terms of officer safety and morale, but also public reassurance and confidence that the police 
have the means to deal effectively with armed crime and terrorism (Waldren 2007). A review by the Inspectorate of Constabulary in Scotland (HMICS 2014) of the standing authority allowing all authorised response vehicle (ARV) officers in Scotland to overtly carry side arms on routine patrol suggested that, although the operational need for the authority was justified, the authority had not considered the impact on public perceptions. If one argument for routinely arming police is to provide reassurance to the public, it is important to measure and understand public views about firearms officers, and the extent of support for this policy trend. In this paper, we do not make any judgements about whether and to what extent arming police is a necessary or effective means to deal with the rise in armed crime and terrorism, although we believe there is currently a danger of a drift toward a fully armed force without adequate consideration of the possible effect on police-public relations and indeed the very nature of British policing. Instead, we focus on developing an understanding of public perceptions of armed police, and on why people might support, or oppose, the arming of more officers.

\section{Public reactions to armed police}

'The police do not prevent crime. This is one of the best kept secrets of modern life. Experts know it, the police know it, but the public does not know it. Yet the police pretend that they are society's best defence against crime ... This is a myth.' (Bayley 1994, p. 2)

David Bayley and others (e.g. Vitale 2017) have long argued that public views about the true nature and function of police are often fundamentally wrong. While this view risks over-statement - people are certainly more knowledgeable about the police than about other criminal justice institutions such as the courts and prisons - our analysis is nevertheless based on the important underlying assumption that most people living in the UK are, in relation to armed policing, operating in a 'low information environment'. 
They will, by and large, have experienced a domestic social and political context within which even the sight of armed police remains relatively rare, and more importantly they will have little or no explicit knowledge about the aims and duties of such officers, the circumstances in which firearms can legally be used, or the efficiency and efficacy of this mode of policing versus others. What they will have is a general sense of what armed police are 'for' (i.e. combatting armed offenders and particularly terrorists, providing for a more assertive or aggressive form of policing, or indeed both), and an emotional or affective response to the sight or idea of police officers carrying guns.

Research on public acceptance (or rejection) of new technologies and scientific advances has shown that when knowledge and experience are lacking, people's emotional response to an issue (i.e. their 'affect') is central in informing their stance toward it (e.g. Siegrist et al. 2007, Midden and Huijts 2009, Merk and Pönitzsch 2017). The licensing and control of gene-and nanotechnologies, or the introduction of environmental controls and green technologies are, like specialist police tactics and strategy, issues about which most people have little direct knowledge or experience, yet are increasingly required to make judgements about, by voting for politicians who support or oppose such measures, or more concretely in terms of whether they avoid or adopt a particular technology. The 'affect heuristic' (Slovic et al. 2002, 2004) suggests that in the absence of knowledge and direct experience, emotional responses to new technologies and those implementing them influence assessments of the associated risks and benefits, and willingness to support or oppose their introduction or uptake.

This body of work has also demonstrated a close link between trust and affect: affective responses to a particular issue are shaped at least in part by trust in relevant actors. Public trust in the police is of course a key part of the criminological literature. Research shows that trust in the police is linked to public cooperation, willingness to 
grant police discretion, and even propensities to obey the law (Tyler and Huo 2002, Sunshine and Tyler 2003, Jackson and Bradford 2010). Trust informs people's willingness to accept police presence, police action, and officers' ability to issue orders and directions.

The extent to which people trust the police is based in part on judgments of efficacy and technical competence (Jackson et al. 2012): but other factors are as or more important. People want a police force that is effective, but also one that is fair, aligned with their own values and restrained in its use of power (Jackson et al. 2012, Trinkner et al. 2017). On this account, trust is formed on the basis of expectations and evaluations of the extent to which police treat members of the public fairly when exercising their authority, have the right motives, and act in the best interests of the public - when, that is, they believe police have good intentions toward the policed (Tyler and Huo 2002, Jackson and Bradford 2010). This type of motive-based trust involves the expectation that the police and the public share social bonds. People want to feel the police are working on behalf of the community and that they have a commitment to shared interests and priorities: they expect the police to be a 'civic guardian' who embodies community norms and values (Jackson and Bradford 2010). Trust flows from the extent to which they feel police live up to these expectations.

This concept of trust resonates strongly with that applied in the literature on public acceptance of new technologies. As Midden and Huijts note (2009, p. 744), 'many authors ... adopt the view that the concept of trust refers to a feeling that another person is caring, morally good, and has positive intentions toward the person who trusts. This creates a willingness to accept vulnerability [in relation to the potential actions of the object of trust].' Two consequences flow from this account. First, when people think about a new development (here, the arming of police officers; for Midden and Huijts, 
carbon capture and storage) about which they have little direct, personal, knowledge, trust in the actor(s) concerned evokes positive affect in relation to the development being enacted. Since trust is intimately linked to positive evaluations of those implementing the change, this makes acceptance of it more likely. A lack of trust will do the opposite, evoking negative affect and resistance.

Second, the notion that a willingness to accept vulnerability lies at the heart of trust is increasingly well accepted in the literature on this topic (PytlikZillig and Kimbrough 2015): to place trust in another is to willingly accept one's vulnerability to their potential (mis)deeds. This seems especially relevant when considering the arming of police. Although police in the UK rarely discharge their weapons (there were 10 incidents in which police firearms were discharged in the year ending March 2017, up from 7 the previous year, Home Office 2017), high-profile police shootings in which unarmed civilians have been killed (e.g. Jean Charles de Menezes, James Ashley) show the public are certainly more vulnerable to mistakes made by armed versus unarmed police officers. The literature suggests those who trust police will be more likely to accept more armed police because they are more willing to accept such vulnerability.

It is therefore not surprising that trust, and related questions of legitimacy and shared group membership, have shown to be key predictors of how people think about police potential for, and use of, force. Recent research by the IPCC (2015) found a high level of trust in the police to use reasonable force - more than four in five people interviewed said they trust the police (either a lot or a fair amount) to use reasonable force. But people from Black, Asian and Minority Ethnic (BAME) groups, younger people, and those living in London were found to have less positive views regarding police use of force and, typically, those who had experienced police use of force had a negative view of the police as a result of this direct experience. More widely, intrusive 
police tactics are more likely to be tolerated when people trust the motives that drive those tactics. On this account, public trust gives police greater discretionary authority because it motivates a sense that whatever the police are doing, they are doing it for the right reason (Tyler and Huo 2002). Moreover, those who identify more strongly with the social group the police represent are more accepting of police use of force (Bradford et al. 2017), for reasons of basic ingroup solidarity but also because shared group membership is linked with trust.

There is then much to suggest that trust (or distrust) in police will be linked to reactions to armed police. People who view police as having the right intentions toward those they serve, and as effective in the tasks assigned to them, may respond more positively to armed officers: because they have a generally positive affect toward police; because they are confident the firearms will be used appropriately and to good effect; and because they are more willing to be vulnerable to police power. Those who have less trust, however, may feel otherwise, resulting in a negative affective response to the sight or idea of armed police, characterised for example by fear, aversion or defiance, and a reluctance to be more vulnerable to police power than they already are. As a result, trust seems likely to be linked directly, indirectly via affect, or both, to policy preferences in relation to increasing the number or presence of armed police. Figure 1 shows the basic conceptual map that therefore guides our analysis.

[Figure 1 near here]

\section{Other predictors of responses to armed police}

Conceptualizing the basic 'structure of feeling' around the question of arming police allows for the fact that many other factors may shape public reactions to armed police. For current purposes these can be grouped into three broad and sometimes overlapping 
categories. First, those that influence people's affective response to armed police via (mediated by) their trust judgements. Second, those that directly influence affect. Third, those that directly influence policy preferences in ways independent of trust and affect. We outline below five groups of variables that may fit one or more of these categories.

\section{Neighbourhood context}

The structural (e.g. poverty, crime) and social (e.g. collective efficacy, social cohesion) characteristics of neighbourhoods have been shown to be important predictors of trust in police (e.g. Sampson and Bartusch 1998, Jackson et al. 2012), and thus, perhaps, of affective responses to armed police. It could be that people who live in more disorderly, less cohesive and more crime-affected areas will react negatively to armed police because they tend to trust police less. Yet, another possibility is that those who live in such areas will have a more positive emotional response to armed police because they feel a more assertive, 'powerful' form of policing is needed in their neighbourhood (c.f. Bradford and Jackson 2017). These judgements may be distinct from trust because they relate to the need for police. Area conditions and character could therefore have a complex relationship with people's views on armed police.

\section{Psychological variables}

While a whole range of psychological needs, attitudes and beliefs might shape people's responses to armed police, we concentrate here on those most proximate to notions of policing and crime. Specifically, people who are more concerned about crime and perhaps particularly terrorism may be more positive toward the idea and sight of armed police. Similarly, those with a higher need for order - for example, those with more authoritarian mind sets - might be expected to be more positive about the idea of an armed police service since this represents a more visible, firmer assertion of order. In 
both cases any association is likely to be largely independent of trust, because they relate to what policing should be like (stronger, firmer, tougher).

\section{Socio-demographic variables}

Socio-demographic variables could shape responses to armed police in a number of ways. First, people from groups and categories less trusting of the police - such as those from some ethnic minority groups - may experience a less positive affective response to armed police because of this lower level of trust. Second, people from groups and categories who perceive a greater vulnerability to crime, such as women, those with disabilities or recent victims of crime (ONS 2017) may have a more positive affective response to armed police because, as above, this constitutes a more visibly powerful form of order maintenance and 'crime-fighting'. Third, those from groups and categories who have historically been or who currently are vulnerable in relation to police may have a less positive affective response (e.g. Bowling \& Philips 2007): people from ethnic minority, LGBT, or other marginalized social categories may have less positive affect because they find it easier than others to imagine police threatening or indeed harming them.

\section{Terrorist events}

In recent years the site of our study, London, has experienced a number of high profile terrorist attacks. It would seem prima facie likely that, independent of trust in the police, such an attack would influence both residents' affective response to armed police - as a symbol of action and protection - and their policy preferences in relation to arming police. Since a terrorist attack provides some information about the actual risk and pattern of such events (i.e. that they can and do occur, and during them armed police can provide a vital part of the response), this may encourage some people to support the 
arming of more police irrespective of their trust in police or their emotional response to armed officers. What this may mean in practise is that those who are questioned about their views of armed police in the immediate aftermath of a terrorist event may be more positive than those questioned at other times, when such events are less salient and people are therefore more reliant on heuristics when forming their judgements.

\section{Exposure to armed police}

A final potentially important factor may be exposure to armed police. Familiarity may breed comfort; those who see and interact with armed police more regularly may have less negative affect because they are less surprised, and possibly less alarmed, when they come across or think about armed officers. London is a particularly interesting place to explore this idea, and for two reasons. First, armed police are regularly deployed in some parts of the capital, not only around high profile sites such as the Houses of Parliament and Buckingham Palace, but also on a local level in response to 'surges' of knife-crime and other circumstances. Some Londoners will be more exposed to deployments than others. Second, many people living in London were born and raised outside the UK, and therefore in almost every case in countries where police are routinely armed. These may again prompt a different affective response to the idea of armed police.

\section{Summary}

In sum, we predict a range of variables will be associated with affective responses to the idea of armed police, and the extent of support for policies that would lead to the arming of more police. While trust and affect should be the strongest direct predictors of policy preference, psychological, socio-demographic and neighbourhood level variables may have largely indirect associations with policy preference (via trust and affect). Temporal 
proximity to terrorist attacks may be associated directly with policy preference, as well as indirectly via affect.

\section{Data/Methods}

\section{Participants}

Data are drawn from a sample of 12,821 respondents to the Mayor's Office for Policing and Crime's (MOPAC) Public Attitude Survey (PAS). The PAS is conducted on a rolling basis and includes a representative sample of residents from across London. Approximately 3,200 Londoners are interviewed face-to-face each quarter at preselected addresses aiming to achieve 100 interviews in each of the 32 London boroughs. Participants in this study were interviewed over four quarters between October 2016 and September 2017. The PAS asks about people's experiences of crime and anti-social behaviour, and about their trust in police. The dataset available to us contained electoral ward identifiers, meaning we were able to take some account of the possible association between area-level factors and perceptions of armed police, although we recognise at the outset that electoral ward is a highly imperfect measure of 'neighbourhood' or 'local area'. Some 629 wards were represented in the dataset used for analysis, with an average of 20 respondents per ward.

\section{Constructs and measures}

The PAS contains a range of questions employing Likert-type scales, which are used here to measure the key constructs of interest. Unless otherwise stated all items were measured on a five-point scale that ranged from strongly disagree to strongly agree. Confirmatory Factor Analyses (CFA) in the package Mplus 7.2 was used to derive and validate latent variables for analysis. All observed indicators were set to ordinal, and 
Full Information Maximum Likelihood Estimation was used such that cases with some missing values were not dropped from the analysis. See the Appendix Table for item wordings and factor loadings.

\section{Support for policy}

To measure support for armed police (i.e. their 'policy preference'), participants were asked the question: "The Metropolitan Police Service is currently increasing the number of officers carrying a firearm as part of their routine patrols. To what extent do you agree or disagree that this is a necessary step to keep London safe?" Note that this item was fielded only over the period October 2016 to March $2017(n=6,386)$. It was subsequently dropped due to policy decisions concerning armed police having been made. $^{2}$

\section{Affective response}

To measure participants' reactions to armed police (i.e. their 'affective response'), two items were used: "It makes me feel safer when I see a police officer with a firearm" and "If I saw an officer with a firearm I would feel comfortable approaching them".

\section{Trust in the police}

Two aspects of trust in the police were used in this study. First, trust in police effectiveness was measured using 10 items. For example, participants were asked: "How well do you think the police prevent terrorism?" and "How well do you think the police provide a visible patrolling presence?" For these items, participants responded

\footnotetext{
${ }^{2}$ Aside from the questions about firearms officers, all other measures used in this study are routinely included in the PAS. The armed police questions were added in October 2016 due to an interest in understanding levels of public support for arming police.
} 
on a 7-point scale, ranging from 1 being not at all well to 7 being very well. Second, trust in police fairness/engagement (broadly, their 'good intentions') was measured using eight items, including "To what extent do you agree or disagree the police in this area listen to the concerns of local people?" and "To what extent do you agree or disagree the police in this area treat everyone fairly regardless of who they are?"

\section{Neighbourhood context}

Ward-level 2011 Census and police recorded crime data from 2011/12 were used to measure the 'structural' characteristics of respondents' neighbourhoods. We created a measure of concentrated disadvantage using Census variables such as employment rate, rate of income support, life expectancy and proportion of social rented housing in the area. High scores on this measure indicated a ward had high levels of disadvantage. We also included two area-level control variables: population density and proportion BAME.

Collective efficacy was measured using eight PAS items relating to respondents' perceptions of social cohesion and informal social control in their neighbourhood. For example, "People in this neighbourhood can be trusted" and "The people who live here can be relied upon to call the police if someone is acting suspiciously". Along with exploring individual level measures of collective efficacy, we generated an area level measure by taking the mean score of respondents within each ward. Conditioning on individual level perceptions of collective efficacy, this latter can be considered a measure of neighbourhood characteristics (c.f. Sampson 2012).

\section{Worry about crime}

Worry about crime and anti-social behaviour was measured using two PAS items: "To 
what extent are you worried about crime in this area" and "To what extent are you worried about anti-social behaviour in this area". Participants responded on a 4 point scale: $1=$ very worried, $2=$ fairly worried, $3=$ not very worried and $4=$ Not at all worried. Participants were also asked how worried they were about terrorism, both in their local area and in London, using the same four-point scale above.

\section{Authoritarian attitudes}

One question from the PAS was used to measure the extent of respondents' authoritarian attitudes: "Thinking about society more generally, to what extent do you agree or disagree that people who break the law should be given stiffer sentences". This was entered into models as a single item (see Table 2).

\section{Sociodemographic variables}

The PAS records a number of sociodemographic characteristics of respondents. The following variables were used in analysis: age, gender, ethnicity, country of birth, sexuality, disability status, employment status, and education level. Respondents were also asked whether they had been a victim of crime in the past 12 months.

\section{Exposure to armed police}

The rate of gun and knife crime in respondents' boroughs was used as a proxy for exposure to armed police because firearms deployments correlate with gun and knife crime incidences (College of Policing 2013), with decisions being taken at, broadly speaking, the borough level. A dummy variable was created splitting the 32 boroughs into high or low rates of gun and knife crime - armed police are deployed much more often in the former group of boroughs. Respondents were also asked whether they had seen an armed police officer in the preceding three months. 


\section{Results}

\section{Descriptive statistics}

Table 1 presents the mean affective response and proportion of support for policy across the different sociodemographic characteristics. At a glance, these descriptive statistics reveal some variation across different groups of respondents. People with black Caribbean and mixed ethnicities, women, younger respondents, students and LGBT respondents had the most negative affective response, and the lowest levels of support for armed police. Table 2 presents pairwise correlations between affect and support for policy and the other interval-ratio level variables used in the analysis. Affective response and support for policy were most strongly correlated with trust in police fairness and effectiveness, and worry about terrorism in London. There was a strong positive correlation between affect and support for policy.

[Table 1 near here]

[Table 2 near here]

\section{Multivariate analysis}

We first used multi-level modelling to explore variation in affective responses to armed police. Table 3 shows the results of a series of multi-level linear regression models predicting positive affect toward armed police.

Model 1 first tested whether temporal proximity to terrorist attacks influences emotional responses to armed police. We predicted that people who are questioned in the immediate aftermath of a terrorist event would have a more positive affective response to armed police than those questioned at other times. Dummy variables were created identifying interviews conducted within a week of each of the five terror attacks 
that occurred during the time period for this study. ${ }^{3}$ As Table 3 shows, there was no significant difference in affect immediately following any of the five terror attacks compared to other times. ${ }^{4}$ However, over time, there was a significant, although very small, increase in positive affect toward armed police.

\section{Exposure to armed police}

Model 2 included indicators of the level of exposure to armed police. Findings showed that residents of boroughs with high rates of gun and knife crime (and therefore a higher level of police firearms deployments) had on average a more negative affective response to armed police. This was a moderate effect. One interpretation of this finding is that higher exposure to armed police leads to more negative affect toward them. However, whether or not an individual had themselves seen an armed police officer in the last three months did not predict affect, suggesting that some other factor(s) is in play (see below).

[Table 3 near here]

Does neighbourhood context matter?

Model 3 added variables relating to the structural and social characteristics of the neighbourhood in which people live. Results showed structural characteristics of the

\footnotetext{
${ }^{3}$ Westminster attack 22 March 2017, Manchester attack 22 May 2017, London Bridge attack 3 June 2017, Finsbury Park Mosque 19 June 2017 and Parsons Green Tube 15 September 2017.

${ }^{4}$ Models were also run looking at interviews conducted within two days of each attack; again, there was no significant spike in positive affect toward armed police.
} 
neighbourhood in which people live did not significantly predict affective responses to armed police (with the exception of the proportion of BAME residents in the ward which had a very small positive statistical effect). However, social characteristics of the neighbourhood did predict affect. People who perceived there to be a high level of collective efficacy in their neighbourhood - and those who lived in an area with a higher level of collective efficacy - had a more positive emotional response to armed police than those who reported low levels of collective efficacy. The effect size was larger for individual perceptions of collective efficacy. Another interpretation of these findings is that people who live in areas of high collective efficacy and are themselves very positive about social cohesion and the neighbourhood's collective ability to regulate itself are particularly likely to be positive about armed police.

\section{Social-demographic variables}

In Model 4, we added a number of socio-demographic variables. Taking account of neighbourhood context and exposure to armed police, there were a number of statistically significant independent associations with affective responses to armed police. Firstly, as expected, compared to White people, people of all BAME ethnicities (except Indian) had significantly more negative affect toward armed police. The largest effect sizes were for people of black Caribbean and Bangladeshi ethnicities. Also consistent with our predictions, younger respondents (those aged between 16 and 24 years) were significantly less positive toward armed police than respondents in every other older age category. Furthermore, as predicted, LGBT respondents had significantly less positive affect toward armed police than heterosexual respondents.

Vulnerability to crime also predicted affective responses to armed police, but in the opposite direction to our hypotheses. Females and recent victims of crime had less positive affect toward armed police than males and non-victims. Disability was not a 
significant predictor. Individuals who were born outside the UK had a more positive affective response to armed police than those born in the UK - it may indeed be that experiencing life in countries were police are routinely armed makes people more comfortable with the thought of armed police in the UK. This was a moderate effect.

\section{Psychological variables}

In Model 5, we included variables relating to participants' notions of policing and crime. Consistent with predictions, respondents who reported being worried about crime and ASB in their local area were significantly more positive about armed police than respondents who were not worried about crime. Similarly, people who were worried about terrorism in London had a more positive affective response. Interestingly, worry about terrorism in their local area did not predict respondents' emotional response to armed police, perhaps because they tended to view it as an unlikely occurrence $(61 \%$ of the sample reported being worried about terrorism in London compared to only $18 \%$ being worried about terrorism in their local area). People who held more authoritarian attitudes (i.e. who thought sentences should be longer) had a more positive affective response to armed police, as expected. When these psychological variables were added into the model, both age and sexuality lost their independent predictive power. All other significant socio-demographic and neighbourhood effects remained.

\section{Trust in the police}

Our final model (Model 6) added trust in the police. Respondents' level of trust in the police made an independent, significant, contribution to the model. In other words, regardless of the neighbourhood in which people live, who they are, or their notions about crime and policing, people who trust the police to effectively deal with crime, and in particular to behave in a fair and just manner, respond more positively to armed 
police. Trust in police fairness/engagement had the largest effect size in the model, suggesting that, above all else, people who believe the police behave in a fair and just manner are the most accepting of armed police. Consistent with our predictions, when trust was added to the model the coefficients for collective efficacy and borough gun/knife crime weakened, suggesting some evidence of mediation effects. However, the coefficients of many of the significant predictors were not altered substantially by the addition of trust, suggesting that the associations between these variables and affect was not, by and large, mediated by trust.

\section{Affect and trust as predictors of policy preference}

Next, we estimated a series of regression models, exactly as above, but this time with policy preference as the outcome variable. There was a similar pattern of results, with trust in police intentions, authoritarian attitudes and worry about crime and terrorism having the largest effect sizes. ${ }^{5}$ However, when affective response to armed police was added to the model, many of the other variables lost their predictive power. In fact, only three variables were independently predictive in this model: authoritarian attitudes and worry about terrorism (both locally and in London). Conditioning on affect, neither trust in police fairness/engagement nor trust in police effectiveness predicted policy preference, suggesting the association between trust and support for policies that would lead to the arming of more police is mediated by people's emotional response toward armed police. Finally, respondents interviewed in the aftermath of the Westminster Bridge attack (the only one that occurred during the period in which the policy question was fielded) were no more likely than others to support the arming of more police.

\footnotetext{
${ }^{5}$ Coefficients for these models are not presented here. Contact the corresponding author for the supplementary table.
} 
To further explore the extent to which affect acts as a mediator of trust, we estimated a Structural Equation Model (SEM) in the package Mplus 7.2. The SEM includes the key constructs of interest in this study (affect, and trust in police fairness and effectiveness) and the three significant predictors above (worry about terrorism and authoritarian attitudes). Figure 2 presents standardised path coefficients between the variables and Table 4 presents estimates of the indirect effects. Fit indices suggested a good fit to the data $\left(\chi^{2}(209)=4376.23, p<.001 ; \mathrm{RMSEA}=.04 ; \mathrm{CFI}=.99 ; \mathrm{TLI}=.99\right){ }^{6}$

[Figure 2 near here]

[Table 4 near here]

Table 4 shows there are significant indirect relationships between four of the predictor variables and policy preference via affect. As shown in Figure 2, emotional response to armed police fully mediates the relationship between trust in the police and support for policy ${ }^{7}$, and partially mediates the relationship between worry about terrorism in London and authoritarian attitudes and policy preference - these variables still independently predict support for policy when affect is taken into account, but the relationship between trust in the police and support for policy is mediated entirely by affect. In other words, people who view the police has having the right intentions toward them, and as effective in the tasks assigned to them, respond more positively to

\footnotetext{
${ }^{6}$ Although a non-significant chi-square is preferable, there are a number of problems with using significance levels for the chi-square as a guide to fit. The chi-square is likely to produce conservative estimates of fit when the sample is large, and when there are many variables.

${ }^{7}$ The path coefficients between trust and support for policy switched signs when affect was controlled for. This is likely to be a residual effect due to multi-collinearity.
} 
armed police, which in turn influences their policy preferences in relation to increasing the presence of armed police on the streets.

It is worth reiterating the strength of the association between positive affect and policy support. A standardized beta of .88 suggests these are very nearly the same 'thing', empirically if not conceptually. Among respondents to the PAS, a positive affective response to armed police was almost coterminous with a view that arming more is appropriate. This may be in part an artefact of the survey - the three items concerned are asked one after another during the interview - but it also seems likely to reveal something about the way people think about this kind of policing policy change. We return to this point below.

\section{Discussion}

The relationship between police and the public is critically important to maintaining public safety and effective policing. Recent terrorist attacks in the UK and Europe have brought the issue of whether police officers in England, Wales and Scotland should be routinely armed to the forefront of debate, raising questions about how members of the public will respond to such developments. This paper provides a timely exploration of public perceptions and acceptance of armed police in London. In a context where many people are even now not used to this form of policing, and in which they likely have little direct knowledge about the duties and abilities of firearms officers, the rules governing their deployment, and the effectiveness of this mode of policing, we asked: who supports the arming of police officers, who does not, and why?

Our findings are consistent with research into public acceptance of new technologies which shows that when knowledge and experience are lacking, people's emotional response to an issue drives their stance toward it (Merk and Pönitzsch 2017, Midden and Huijts 2009, Siegrist et al. 2007). Consistent with the 'affect heuristic' 
(Slovic et al. 2002, 2004), we find in the current study that, of the variables tested, affect was by some margin the strongest driver of support for armed police. Londoners seem to rely on how they feel about armed police to inform their decision of whether or not to support a policy to arm more police officers. Previous research into public acceptance of new technologies has also found a close link between trust and affect; people's affective response to an issue is shaped by the extent to which they trust the relevant actors and are willing to accept vulnerability (Midden and Huijts, 2009). Again, our findings parallel this research. Trust in police fairness (and to a lesser extent trust in police effectiveness) was a strong predictor of affect, and, through affect, trust shaped people's policy preferences. The more people trust the police, the more positive they feel toward armed police, and the more willing they are to accept a policy that would give the police more power, and make them more vulnerable to the potential abuse of that power.

Naturally, the reverse relationship than what we specify in our models could also be true. Instead of trust in the police influencing how people respond to armed police, the act of arming more (or all) police might alter the relationship between the police and the public and have an effect on trust. This possibility is especially relevant in London where firearms deployments are relatively common and trust in some communities is already low. More research is needed on the impact of exposure to armed police on people's affect toward armed police, and their attitudes and levels of trust in the police more generally.

The models in the current study showed a number of additional predictors of acceptance of armed police, with relevant statistical associations often mediated by trust and particularly affect. Groups with historically low levels of confidence and trust in the police (e.g. BAME groups, LGBT and younger people) were the least positive toward 
armed police, and were the least supportive of policies aimed at increasing the presence of firearms officers. Females, recent victims of crime and UK-born respondents also showed more negative responses to the idea of armed police. Furthermore, we found that people's perceptions of the social characteristics in the area in which they live (e.g. levels of social cohesion) were more important for predicting responses to armed police than the structural characteristics, such as, most notably, crime. These findings are largely consistent with previous research into police trust, which has shown that structural characteristics are less important than the social characteristics of a neighbourhood in predicting trust and legitimacy (Jackson et al. 2012). Psychological variables, such as authoritarianism and worry about crime and terrorism, also emerged as important predictors of attitudes toward armed police.

We also tested whether temporal proximity to a terrorist event affects people's views toward armed police. After all, one argument for increasing the presence of armed police is to provide reassurance to the public that the police have the means at hand to effectively deal with terrorism. There was no significant spike in affective responses to armed police immediately following any of the high-profile terror attacks that occurred during the time period covered by the PAS data. Those questioned about their views in the immediate aftermath of a terrorist event had similar views to those questioned at other times. One explanation for this finding is that, because terror attacks are a relatively frequent occurrence in London (in the one-year time period for this study, there were four such attacks) - and the capital has a long history of suffering such events - terrorism is always a salient factor for Londoners, or, alternatively, a less salient factor than it would be in contexts with less experience of terrorism. On the other hand, it could be that people do not believe increasing the presence of armed police would place them at any reduced risk of being a victim of terrorism, minimising the 
extent of any positive response in the aftermath of an attack. Other analysis using the PAS has found that worry about terrorism spikes in the immediate aftermath of terrorist attacks (MOPAC, personal communication, 12 October 2017), yet we find here that support for armed police remains constant.

The analysis above suffers, of course, from a number of limitations. First and most obviously, we cannot estimate causal effects from our cross-sectional data - all we have shown is that trust, affect and other variables are correlated with people's preferences for more armed police. Second, the analysis was limited by the variables available in the PAS. Our measure of affect was limited to just to two items, and thus did not include all the possible components of emotional responses to police (e.g. fear, anger, pride, warmth). More intriguingly, it seems likely that authoritarian attitudes are an important aspect of people's feelings toward armed police, yet our measure here was very blunt, meaning only tentative conclusions can be drawn. Finally, we have not been able consider how other attitudes toward police - such as legitimacy judgements or concerns about distributive fairness - might 'fit' into the relationships described above. In sum, given the paucity of research in this area we believe this paper is a useful first step in considering the way people think about and react to armed police, but it is only that, and more research will be needed to address these and other questions.

\section{Conclusion}

In this paper we have shown that people's affective response to armed police is a perhaps the - key factor shaping their response to a policy aimed at increasing the number of armed officers in London. Affect, in turn, is strongly predicted by trust in the police, along with a wide range of other socio-demographic, psychological, and social variables. By contrast, immediate temporal proximity to terror attacks was not associated with either affect or policy preference. Lacking direct knowledge of what 
armed police can do and achieve, people fall back on emotion, feeling, and trust to form preferences about policy.

While the relevance of this study may seem limited to the internationally unusual context of (unarmed) British policing, this may not be the case. People in the UK thinking about other developments in policing technology and equipment - such as the use of drones or facial recognition technology - may similarly draw upon trust and affect when forming their judgements. Internationally, calls to increase the firepower routinely available to police and/or visible in routine policing may be processed in a similar manner, as of course may other changes such as those noted above. Further research is needed to test these claims.

We close this paper with two further, and somewhat contrasting, observations. First, one interpretation of the findings presented here is that support for or opposition to the arming of more police was in large part determined by what people already thought of police. While the cross-sectional nature of the PAS data severely limits the conclusions we can draw, it is possible that routinely arming more officers will have no effect on trust and reassurance, because these are precisely the factors that shape how people react to armed police. Which is not to suggest that public opinion on this matter is static, as the slow upward drift in affect over the survey period suggests, but it is certainly quite stable. The way people react to change in policing is likely to be very heavily influenced by what they already think of police.

Second, what we have described may be an accurate description of how people 'actually' think about armed police, and the ways they reach decisions on policy concerning this issue. But this is probably not how decisions should be made. Ideally, people would have sufficient information to make informed choices about a fundamental change to the nature of British policing, such that they would not have to 
rely on how this made them feel (which is not to argue that feelings of safety or fear should be considered irrelevant). One of the challenges police and policy-makers are likely to face in the coming years, as new technological developments are increasingly taken up by police organizations, will be not only 'bringing people along' with such changes but, more importantly, providing them with enough relevant information to come to judgements and preferences informed by facts and feelings. 


\section{References}

Bayley, D. H. 1994. Police for the future. New York: Oxford University Press.

BBC, 2016. Met police to get 600 more armed police to boost terror response. Available from: http://www.bbc.co.uk/news/uk-35308467 [Accessed 20 January 2018].

BMG Research, 2015. Evening Standard/BMG Poll: 58\% believe officers should be routinely armed in wake of Paris Attacks. Available from: http://www.bmgresearch.co.uk/eveningstandardbmg-poll-58-believe-officers-should-be-routinely-armed-in-wake-of-paris-

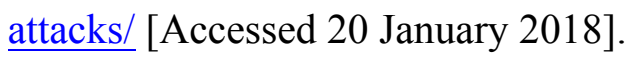

Bowling, B. and Philips, C., 2007. Disproportionate and discriminatory: Reviewing the evidence on police stop and search. The Modern Law Review, 70, 936-961.

Bradford, B., Milani, J. and Jackson, J., 2017. Identity, legitimacy and "making sense" of police use of force'. Policing: An International Journal, 40(3), 614-627.

College of Policing, 2013. Deployment of AFOs. Available from:

https://www.app.college.police.uk/app-content/armed-policing/use-of-force-firearmsand-less-lethal-weapons/deployment-of-afos/ [Accessed 13 February 2018].

HMICS, 2014. Review of standing firearms authority for armed response vehicle crews within Police Scotland. Available from: https://www.hmics.scot/publications/review-standingfirearms-authority-armed-response-vehicle-crews-within-police-scotland [Accessed 1 February 2018].

Home Office, 2011. CONTEST: The United Kingdom's Strategy for Countering Terrorism. Home Office. Available from: https://www.gov.uk/government/publications/counterterrorism-strategy-contest 
Home Office, 2017. Police use of firearms statistics England and Wales April 2016 to March 2017. Available from: https://www.gov.uk/government/statistics/police-use-of-firearmsstatistics-england-and-wales-april-2016-to-march-2017-data-tables [Accessed 22 January 2018].

IPCC, 2015. Police use of force. Available from:

https://www.policeconduct.gov.uk/sites/default/files/Documents/researchlearning/BMRB use of force report.pdf

Jackson, J. and Bradford, B., 2010. What is trust and confidence in the police?'. Policing: A Journal of Policy and Practice, 4(3), 241-248.

Jackson, J., et al., 2012. Just authority?: Trust in the police in England and Wales. Routledge.

Merk, C. and Pönitzsch, G., 2017. The role of affect in attitude formation toward new technologies: The case of stratospheric aerosol injection. Risk Analysis, 37(12), 22892304.

Midden, C. J. and Huijts, N., 2009. The role of trust in the affective evaluation of novel risks: The case of CO2 storage. Risk analysis, 29(5), 743-751.

ONS, 2017. Public perceptions of crime in England and Wales: year ending March 2016. Available from: https://www.ons.gov.uk/peoplepopulationandcommunity/crimeandjustice/articles/publicp erceptionsofcrimeinenglandandwales/yearendingmarch2016

Police Federation, 2017. Increased support for routine arming. Available from: http://www.polfed.org/newsroom/4954.aspx

PytlikZillig, L. M. and Kimbrough, C. D., 2015. Consensus on Conceptualizations and Definitions of Trust: Are We There Yet? In: E. Shockley, T.M.S. Neal, L. PytlikZillig, 
and B. Bornstein, eds. Interdisciplinary Perspectives on Trust: Towards Theoretical and Methodological Integration. New York: Springer, 17-47.

Sampson, R. J., 2012. Great American city: Chicago and the enduring neighborhood effect. University of Chicago Press.

Sampson, R. J. and Bartusch, D. J., 1998. Legal cynicism and (subcultural?) tolerance of deviance: The neighbourhood context of racial differences. Law and Society Review, 32(4), 777-804.

Siegrist, M., et al., 2007. Public acceptance of nanotechnology foods and food packaging: The influence of affect and trust. Appetite, 49(2), 459-466.

Slovic, P., et al., 2002. Rational actors or rational fools: Implications of the affect heuristic for behavioral economics. The Journal of Socio-Economics, 31(4), 329-342.

Slovic, P., et al., 2004. Risk as analysis and risk as feelings: Some thoughts about affect, reason, risk, and rationality. Risk analysis, 24(2), 311-322.

Sunshine, J. and Tyler, T. R., 2003. The role of procedural justice and legitimacy in shaping public support for policing. Law \& society review, 37(3), 513-548.

Trinkner, R., Jackson, J., and Tyler, T., 2017. Bounded authority: Expanding 'appropriate' police behavior beyond procedural justice. Available from: osf.io/preprints/socarxiv/nezm6

Tyler, T. R. and Huo, Y., 2002. Trust in the law: Encouraging public cooperation with the police and courts. Russell Sage Foundation.

Vitale, A. S., 2017. The End of Policing. London: Verso.

Waldren, M., 2007. The arming of police officers. Policing: A Journal of Policy and Practice, 1, $255-264$. 
Appendix

Item wordings and factor loadings for latent variables used in analyses

Factor

loading

Trust in police fairness/engagement

To what extent do you agree with these statements about the police

in your area?

They can be relied on to be there when you need them 0.766

They would treat you with respect if you had contact with them for $\quad 0.690$

any reason

0.739

are

community

0.822

The police in this area listen to the concerns of local people

0.821

The police in this area are helpful

0.739

The police in this area are friendly and approachable

Trust in police effectiveness

How well do you think the Metropolitan police...

Prevent terrorism

Respond to emergencies promptly

0.712

Provide a visible patrolling presence

0.668

Tackle gun crime

0.779

Support victims and witnesses

0.833

Police major events in London

0.631

Tackle drug dealing and drug use

0.738

Tackle dangerous driving

0.700

Respond to hate crime

0.859

Respond to violence against women and girls

0.812

Affective response to armed police

It makes me feel safer when I see a police officers with a firearm

0.808

If I saw an officer with a firearm I would feel comfortable approaching them

0.907

\section{Collective efficacy}

People in this neighbourhood can be trusted

People act with courtesy to each other in public space in this area

0.753

You can see from the public space here in the area that people take pride in their environment

0.706

Local people and authorities have control over the public space in

this area

0.640

If I sensed trouble whilst in this area, I could get help from people who live here

The people who live here can be relied upon to call the police if someone is acting suspiciously 
If any of the children or young people around here are causing trouble, local people will tell them off get on well together

\section{Worry about crime and ASB}

To what extent are you worried about?

Crime in this area

Fit indices: $\chi^{2}(357)=10746.33, \mathrm{p}<.001 ; \mathrm{RMSEA}=.05 ; \mathrm{CFI}=.97 ; \mathrm{TLI}=.97$ 
Table 1. Descriptive statistics for sociodemographic variables

\begin{tabular}{|c|c|c|c|}
\hline & & $\begin{array}{l}\text { Affective response } \\
\qquad M(S D)\end{array}$ & $\begin{array}{c}\text { Support for policy } \\
\% \text { support }\end{array}$ \\
\hline \multirow[t]{11}{*}{ Ethnicity } & White British $(\mathrm{n}=5,972)$ & $-.01(.67)$ & $66 \%$ \\
\hline & $\operatorname{Arab}(\mathrm{n}=342)$ & $-.01(.77)$ & $61 \%$ \\
\hline & African $(\mathrm{n}=871)$ & $-.13(.79)$ & $61 \%$ \\
\hline & Caribbean $(n=663)$ & $-.28(.76)$ & $49 \%$ \\
\hline & Indian $(n=796)$ & $.11(.64)$ & $75 \%$ \\
\hline & Pakistani $(\mathrm{n}=321)$ & $.03(.67)$ & $70 \%$ \\
\hline & Bangladeshi $(\mathrm{n}=320)$ & $-.04(.75)$ & $61 \%$ \\
\hline & Other Asian $(n=628)$ & $.04(.67)$ & $73 \%$ \\
\hline & Mixed (n=345) & $-.22(.68)$ & $58 \%$ \\
\hline & Other White $(n=2,296)$ & $.09(.69)$ & $70 \%$ \\
\hline & Other Ethnicity $(\mathrm{n}=267)$ & $-.05(.75)$ & $59 \%$ \\
\hline \multirow[t]{2}{*}{ Gender } & Male $(\mathrm{n}=5,838)$ & $.04(.69)$ & $69 \%$ \\
\hline & Female $(n=6,978)$ & $-.06(.71)$ & $63 \%$ \\
\hline \multirow[t]{4}{*}{ Age } & $16-24(\mathrm{n}=1,312)$ & $-.14(.71)$ & $63 \%$ \\
\hline & $25-34(n=2,615)$ & $-.05(.71)$ & $64 \%$ \\
\hline & $35-64(n=6,109)$ & $.01(.70)$ & $66 \%$ \\
\hline & $65+(n=2,750)$ & $.04(.66)$ & $70 \%$ \\
\hline \multirow[t]{2}{*}{ Country of birth } & UK $(n=7,394)$ & $-.07(.69)$ & $64 \%$ \\
\hline & Not UK $(n=5,309)$ & $.07(.70)$ & $70 \%$ \\
\hline \multirow[t]{2}{*}{ Sexuality } & Heterosexual $(\mathrm{n}=12,347)$ & $-.01(.70)$ & $66 \%$ \\
\hline & LGBT $(n=254)$ & $-.20(.73)$ & $49 \%$ \\
\hline \multirow[t]{2}{*}{ Disability } & Yes $(n=1,413)$ & $.01(.74)$ & $68 \%$ \\
\hline & No $(n=11,353)$ & $-.02(.69)$ & $66 \%$ \\
\hline \multirow[t]{4}{*}{ Employment status } & Employed $(\mathrm{n}=7,080)$ & $-.02(.70)$ & $66 \%$ \\
\hline & Unemployed $(\mathrm{n}=229)$ & $-.08(.78)$ & $71 \%$ \\
\hline & Student $(\mathrm{n}=791)$ & $-.17(.70)$ & $61 \%$ \\
\hline & Other $(\mathrm{n}=4,721)$ & $.02(.69)$ & $67 \%$ \\
\hline \multirow[t]{3}{*}{ Education level } & Degree $(n=4,874)$ & $-.09(.70)$ & $60 \%$ \\
\hline & No degree $(\mathrm{n}=7,947)$ & $.04(.69)$ & $70 \%$ \\
\hline & No qualifications $(\mathrm{n}=1,934)$ & $.09(.66)$ & $72 \%$ \\
\hline All respondents & $\mathrm{n}=12,821$ & $-.01(.70)$ & $66 \%$ \\
\hline
\end{tabular}

Note: for affective response, negative values represent negative affect; positive values represent positive affect. The sample size for policy preference is approximately halved because the policy question was only fielded over two quarters. 
Table 2. Pairwise correlations

\begin{tabular}{|c|c|c|c|c|c|c|c|c|c|}
\hline & $\begin{array}{c}\text { Trust } \\
\text { fairn } \\
\text { ess }\end{array}$ & $\begin{array}{c}\text { Trust } \\
\text { effec } \\
\text { tive }\end{array}$ & $\begin{array}{c}\text { Collective } \\
\text { efficacy }\end{array}$ & $\begin{array}{c}\text { Worry } \\
\text { crime/ } \\
\text { ASB }\end{array}$ & $\begin{array}{c}\text { Worry } \\
\text { terror } \\
\text { Londo } \\
\mathrm{n}\end{array}$ & $\begin{array}{c}\text { Worry } \\
\text { terror } \\
\text { local }\end{array}$ & $\begin{array}{l}\text { Authorit } \\
\text { attitudes }\end{array}$ & $\begin{array}{l}\text { Affect } \\
\text { response }\end{array}$ & $\begin{array}{c}\text { Suppor } \\
\text { for } \\
\text { policy }\end{array}$ \\
\hline $\begin{array}{l}\text { Trust police } \\
\text { fairness }\end{array}$ & 1 & & & & & & & & \\
\hline $\begin{array}{l}\text { Trust police } \\
\text { effectiveness }\end{array}$ & $.74^{*}$ & 1 & & & & & & & \\
\hline $\begin{array}{l}\text { Collective } \\
\text { efficacy }\end{array}$ & $.57^{*}$ & $.38 *$ & 1 & & & & & & \\
\hline $\begin{array}{l}\text { Worry } \\
\text { crime/ASB }\end{array}$ & $-.32 *$ & $-.32 *$ & $-.58 *$ & 1 & & & & & \\
\hline $\begin{array}{l}\text { Worry terror } \\
\text { London }\end{array}$ & $-.06^{*}$ & $-.09 *$ & $-.15^{*}$ & $.28^{*}$ & 1 & & & & \\
\hline $\begin{array}{l}\text { Worry terror } \\
\text { local }\end{array}$ & $-.05^{*}$ & $-.08 *$ & $-.13 *$ & $.27^{*}$ & $.51 *$ & 1 & & & \\
\hline $\begin{array}{l}\text { Authoritarian } \\
\text { attitudes }\end{array}$ & .02 & .01 & -.005 & .01 & -.01 & .004 & 1 & & \\
\hline $\begin{array}{l}\text { Affective } \\
\text { response }\end{array}$ & $.37^{*}$ & $.29 *$ & $.12^{*}$ & $.06^{*}$ & $.14^{*}$ & $.05^{*}$ & $.05^{*}$ & 1 & \\
\hline $\begin{array}{l}\text { Support for } \\
\text { policy }\end{array}$ & $.22 *$ & $.17^{*}$ & $.06^{*}$ & $.07^{*}$ & $.16^{*}$ & $.11^{*}$ & $.05^{*}$ & $.69^{*}$ & 1 \\
\hline
\end{tabular}

$* \mathrm{p}<.05$ 
Table 3. Multi-level regression models predicting affective response to armed police

\begin{tabular}{|c|c|c|c|c|c|c|c|c|c|c|c|c|}
\hline & Model 1 & & Model 2 & & Model 3 & & Model 4 & & Model 5 & & Model 6 & \\
\hline & $\beta^{1}$ & $\mathrm{se}(\mathrm{B})$ & $\beta$ & $\mathrm{se}(\mathrm{B})$ & $\beta$ & $\mathrm{se}(\mathrm{B})$ & $\beta$ & $\mathrm{se}(\mathrm{B})$ & $\beta$ & $\mathrm{se}(\mathrm{B})$ & $\beta$ & $\mathrm{se}(\mathrm{B})$ \\
\hline \multicolumn{13}{|l|}{ Timing of interview } \\
\hline $\begin{array}{l}\text { Week of interview } \\
\text { Week after Westminster }\end{array}$ & $0.002 * * *$ & 0 & $0.002 * * *$ & 0 & $0.002 * * *$ & 0 & $0.002 * * *$ & 0 & $0.001 * *$ & 0 & $0.002 * * *$ & 0 \\
\hline & -0.04 & 0.05 & -0.04 & 0.05 & 0.003 & 0.05 & 0.003 & 0.05 & 0.003 & 0.05 & -0.003 & 0.04 \\
\hline attack & -0.06 & 0.04 & -0.06 & 0.04 & -0.07 & 0.05 & -0.08 & 0.04 & -0.07 & 0.04 & -0.04 & 0.04 \\
\hline attack & 0.04 & 0.05 & 0.03 & 0.06 & 0.03 & 0.06 & 0.01 & 0.06 & 0.02 & 0.05 & -0.007 & 0.05 \\
\hline $\begin{array}{l}\text { Week after Finsbury Park } \\
\text { attack }\end{array}$ & 0.01 & 0.05 & 0.02 & 0.05 & -0.03 & 0.06 & -0.03 & 0.05 & -0.02 & 0.05 & -0.01 & 0.05 \\
\hline $\begin{array}{l}\text { Week after Parsons Green } \\
\text { attack }\end{array}$ & -0.02 & 0.02 & -0.02 & 0.05 & -0.05 & 0.05 & -0.06 & 0.05 & -0.07 & 0.05 & -0.07 & 0.05 \\
\hline \multicolumn{13}{|l|}{ Exposure to armed police } \\
\hline Borough gun/knife crime & & & $-0.10 * * *$ & 0.02 & $-0.12 * * *$ & 0.02 & $-0.10 * * *$ & 0.02 & $-0.08 * * *$ & 0.02 & $-0.05 * *$ & 0.02 \\
\hline Seen armed officer (ref: no) & & & & & & & & & & & & \\
\hline Yes & & & 0.005 & 0.01 & 0.02 & 0.01 & $0.04 * *$ & 0.01 & $0.05^{* * *}$ & 0.01 & $0.06^{* * *}$ & 0.01 \\
\hline \multicolumn{13}{|l|}{ Neighbourhood context } \\
\hline Population density & & & & & -0.002 & 0 & -0.002 & 0 & -0.002 & 0 & -0.002 & 0 \\
\hline Proportion BAME & & & & & $0.003 * * *$ & 0 & $0.002 * * *$ & 0 & $0.002 * *$ & 0 & $0.001 * *$ & 0 \\
\hline Concentrated disadvantage & & & & & 0.01 & 0.01 & 0.02 & 0.01 & 0.01 & 0.01 & -0.01 & 0.01 \\
\hline $\begin{array}{l}\text { Crime rate } \\
\text { Collective efficacy ward }\end{array}$ & & & & & -0.004 & 0 & -0.005 & 0.01 & -0.005 & 0.01 & -0.002 & 0 \\
\hline $\begin{array}{l}\text { level } \\
\text { Collective efficacy individual }\end{array}$ & & & & & $0.10 * *$ & 0.04 & $0.11 * *$ & 0.03 & $0.07 *$ & 0.03 & 0.03 & 0.03 \\
\hline level & & & & & $0.16^{* * *}$ & 0.01 & $0.15 * * *$ & 0.01 & $0.25 * * *$ & 0.01 & $0.03 * *$ & 0.01 \\
\hline \multicolumn{13}{|l|}{$\begin{array}{l}\text { Socio-demographic } \\
\text { variables }^{3}\end{array}$} \\
\hline \multicolumn{13}{|l|}{ Ethnicity (ref: white British) } \\
\hline Arab & & & & & & & $-0.13 * *$ & 0.05 & $-0.17 * * *$ & 0.05 & $-0.17 * * *$ & 0.04 \\
\hline
\end{tabular}




\section{Black African}

Black Caribbean

Indian

Pakistani

Bangladeshi

Other Asian

Mixed

Other white

Other ethnic group

Country of birth (ref: Not

UK)

UK

Gender (Ref: Male)

Female

Age (ref: 16-24)

25-34

35-64

65 plus

Sexuality (ref: Heterosexual)

LGBT

Disability (ref: No)

Yes

Victim of crime (ref: No)

Yes

Psychological variables

Worry about crime/ASB

Worry about terror attack in

London (ref: not very)

Very/fairly worried

\begin{tabular}{|c|c|c|c|c|c|}
\hline$-0.22 * * *$ & 0.03 & $-0.22 * * *$ & 0.03 & $-0.19 * * *$ & 0.03 \\
\hline$-0.32 * * *$ & 0.03 & $-0.31 * * *$ & 0.03 & $-0.21 * * *$ & 0.03 \\
\hline-0.01 & 0.03 & -0.05 & 0.03 & -0.02 & 0.03 \\
\hline$-0.11^{*}$ & 0.04 & $-0.16 * * *$ & 0.04 & $-0.12 * *$ & 0.04 \\
\hline$-0.23 * * *$ & 0.05 & $-0.23 * * *$ & 0.05 & $-0.20 * * *$ & 0.05 \\
\hline$-0.11 * *$ & 0.04 & $-0.12 * * *$ & 0.04 & $-0.10 * *$ & 0.03 \\
\hline$-0.22 * * *$ & 0.04 & $-0.20 * * *$ & 0.04 & $-0.14 * * *$ & 0.04 \\
\hline-0.04 & 0.03 & -0.03 & 0.03 & -0.01 & 0.02 \\
\hline 0.03 & 0.06 & -0.02 & 0.06 & -0.01 & 0.06 \\
\hline$-0.22 * * *$ & 0.02 & $-0.20 * * *$ & 0.02 & $-0.11^{* * *}$ & 0.02 \\
\hline$-0.11^{* * *}$ & 0.01 & $-0.13 * * *$ & 0.01 & $-0.14 * * *$ & 0.01 \\
\hline $0.07 *$ & 0.03 & 0.04 & 0.03 & 0.04 & 0.03 \\
\hline $0.11 * * *$ & 0.03 & $0.06^{*}$ & 0.03 & $0.07 * *$ & 0.03 \\
\hline $0.09 * *$ & 0.03 & 0.03 & 0.03 & 0.04 & 0.03 \\
\hline$-0.12 *$ & 0.05 & -0.08 & 0.05 & -0.09 & 0.04 \\
\hline 0.03 & 0.02 & 0.03 & 0.02 & 0.004 & 0.02 \\
\hline-0.02 & 0.02 & $-0.06^{*}$ & 0.02 & -0.02 & 0.02 \\
\hline
\end{tabular}

0.01

$0.19^{* * *}$

0.01

$\begin{array}{llll}0.08 * * * & 0.02 & 0.08 * * * & 0.01\end{array}$ 
Not at all worried

Worry about terror attack in

local area (ref: not very)

Very/fairly worried

Not at all worried

Views of sentence (ref:

neither)

Thinks sentences should be

longer

Does not think sentences

should be longer

\section{Trust in police}

Effectiveness

Fairness/engagement

Level one constant

Intraclass correlation

$\mathrm{R}^{2}$ within

$\mathrm{R}^{2}$ between

$\mathrm{N}^{2}$

*p

${ }^{*} \mathrm{p}<0.05, * * \mathrm{p}<0.01, * * * \mathrm{p}<0.001$

${ }^{1}$ Unstandardised coefficients ${ }^{2}$ Data from Kensington and Chelsea and Tower Hamlets are excluded as boundary changes meant the wards in the PAS dataset could not be matched to Census and crime data. We estimated OLS model using the same individual level predictors as above and all 32 boroughs - results were essentially the same as those displayed in Table $3{ }^{3}$ Education level and employment status were also controlled for in the model

$\begin{array}{llll}-0.03 & 0.03 & -0.04 & 0.02 \\ & & & \\ 0.001 & 0.02 & -0.01 & 0.02 \\ -0.005 & 0.02 & -0.01 & 0.02\end{array}$

$0.20 * * *$

0.02

$0.15^{* * *}$

$\begin{array}{llll}-0.15 * * * & 0.03 & -0.14 * * * & 0.03\end{array}$

$0.09 * * * \quad 0.02$

\begin{tabular}{|c|c|c|c|c|c|c|c|c|c|c|c|}
\hline & & & & & & & & & & $.32 * * *$ & 0.01 \\
\hline$-0.06 * * *$ & 0.02 & -0.01 & 0.02 & $-0.09 * *$ & 0.03 & $0.13^{* *}$ & 0.05 & -0.01 & 0.05 & -0.04 & 0.05 \\
\hline 0.06 & & 0.05 & & 0.04 & & 0.03 & & 0.02 & & 0.02 & \\
\hline 0.002 & & 0.002 & & 0.026 & & 0.074 & & 0.124 & & 0.223 & \\
\hline 0.005 & & 0.045 & & 0.159 & & 0.237 & & 0.352 & & 0.446 & \\
\hline 11222 & & 11222 & & 11222 & & 11222 & & 11222 & & 11222 & \\
\hline
\end{tabular}

0.02 
Table 4. Test of indirect effects

\begin{tabular}{lll}
\hline & Estimate & $\boldsymbol{p}$ \\
\hline Trust in police fairness $\rightarrow$ Affect $\rightarrow$ Support for policy & 0.28 & $<.001$ \\
Trust in police effectiveness $\rightarrow$ Affect $\rightarrow$ Support for policy & 0.06 & $<.001$ \\
Worry terrorism (London) $\rightarrow$ Affect $\rightarrow$ Support for policy & 0.12 & $<.001$ \\
Worry terrorism (Local) $\rightarrow$ Affect $\rightarrow$ Support for policy & 0.01 & $=.240$ \\
Authoritarian attitudes $\rightarrow$ Affect $\rightarrow$ Support for policy & 0.03 & $<.001$ \\
\hline
\end{tabular}

